AGNIESZKA PIOTROWSKA-WOJACZYK

Uniwersytet im. Adama Mickiewicza w Poznaniu

\title{
NAZWY RYB W POLSZCZYŹNIE REGIONALNEJ (NA PODSTAWIE DANYCH SŁOWNIKOWYCH)
}

Życie człowieka od zawsze integralnie było związane ze środowiskiem naturalnym i wszystkimi jego elementami, a zwłaszcza z wodą. W dziejach człowieka, wszędzie tam, gdzie istniała określona sieć hydrograficzna,

obok zbieractwa, myślistwa (polowania), rolnictwa i pasterstwa, równie ważne było rybołówstwo. Ten przejaw działalności kulturowej zalicza się do najbardziej archaicznych zawodów i jednej z najstarszych form gospodarki, związanej ze zdobywaniem pożywienia dostarczającego człowiekowi białka i tłuszczu zwierzęcego (...) (Wyrwa 2012: 9).

Nie bez znaczenia pozostaje fakt, że ryby stanowią najliczniejszą grupę kręgowców. Do tej pory wyróżniono ponad trzydzieści dwa tysiące gatunków, przy czym co roku naukowcy odkrywają około stu - stu pięćdziesięciu nowych gatunków. Szacuje się, że nie odkryto jeszcze co najmniej pięciu tysięcy gatunków, głównie ryb głębinowych ze strefy klimatu tropikalnego (Eschmeyer i in. 2010: 19). W Polsce występuje około stu dwudziestu gatunków ${ }^{1}$.

(...), niezależnie od czysto praktycznego, konsumpcyjnego wykorzystania ryb przez człowieka, we wszystkich kulturach zarówno ryba, jak i ludzie ją łowiący - rybacy, znaleźli bardzo szybko swój udział w przestrzeni świata metafizycznego w formie wielu symboli i rozlicznych odniesień związanych z wierzeniami, mitologią, rytuałami i zabobonami (Wyrwa 2012: 10).

Odzwierciedleniem tego jest szereg „rybnych” opracowań z zakresu historii, etnografii, archeologii czy - dokładniej - archeoichtiologii poszczególnych gatunków. Zaskakuje pominięcie owej grupy zwierząt $\mathrm{w}$ dotychczasowych badaniach nad słownictwem języka polskiego. Dysponujemy bowiem monografiami nazw ptaków (Strutyński 1972), nazw owadów (Maciołek 2013), natomiast językowe informacje o nazwach ryb są zwykle

1 Zob. np. Ryby [online]. [dostęp 2 listopada 2016]. Dostępny w Internecie: https://www.medianauka.pl/ ryby. 
rozproszone po rożnych artykułach ${ }^{2}$. Podejmowane przeze mnie zagadnienie jest próbą częściowego wypełnienia luki w naszej wiedzy o ichtiofaunie.

W prezentowanym artykule prześledzę leksykograficzne dzieje wybranych regionalnych nazw ryb. Podstawę materiałową moich ustaleń stanowią bowiem te hasła - nazwy ryb, które jako regionalizmy leksykalne zostały odnotowane w dziełach leksykograficznych $\mathrm{z}$ okresu od początku doby nowopolskiej po przełom XX/XXI wieku. Badaniu zostały poddane następujące dzieła:

- Samuel Bogumił Linde, Słownik jezzyka polskiego, t. 1-6, Warszawa 1807-1814 [SL ${ }^{3}$,

- Stownik języka polskiego, wyd. Maurycy Orgelbrand, cz. 1-2, Wilno 1861 [SWil],

- Jan Karłowicz, Adam Kryński, Władysław Niedźwiedzki, Słownik języka polskiego, t. 1-8, Warszawa 1900-1927 [SW],

- Witold Doroszewski (red.), Słownik języka polskiego, t. 1-11, Warszawa 1958-1969 [SJPD],

- Bogusław Dunaj (red.), Słownik współczesnego języka polskiego, Warszawa 1996 [SWJP],

- Halina Zgółkowa (red.), Praktyczny słownik współczesnej polszczyzny, tom 1-50, Poznań 1994-2005 [PSWP],

- Mirosław Bańko (red.), Inny słownik języka polskiego, tom 1-2, Warszawa 2000 [ISJP],

- Stanisław Dubisz (red.), Uniwersalny słownik języka polskiego, tom 1-4, Warszawa 2003 [USJP].

Zdaję sobie przy tym sprawę, że prace leksykograficzne - co zresztą powszechnie wiadomo - nie są idealnym źródłem wiedzy o słownictwie, w tym zróżnicowanym terytorialnie. Nie ulega bowiem wątpliwości, iż słowniki rejestrują zaledwie wybór leksyki regionalnej. Przy pełnej świadomości ograniczeń, niedoskonałości i niekompletności tego rodzaju opracowań zakładam jednak, że słownictwo w nich odnotowane, zwłaszcza przy uwzględnieniu dużej liczby dzieł, jest w znacznym stopniu charakterystyczne dla języka badanego okresu4

Przy ekscerpcji regionalnych nazw ryb z wyżej wymienionych słowników kierowałam się przede wszystkim eksplicytnymi wskazaniami ich twórców w postaci kwalifikatorów geograficznych (prowincjonalny, regionalny), uwzględniając jednakże wskazówki zawarte explicite lub implicite $\mathrm{w}$ definicjach znaczeniowych, przykładach użycia haseł (Walczak 1997) bądź wynikające $z$ wiedzy o językowej biografii autorów cytowanych przykładów5.

W rezultacie wydzieliłam dziewiętnaście haseł - nazw ryb, z których każde przynajmniej w jednym z uwzględnionych słowników pojawiło się z interesującym mnie geogra-

${ }^{2}$ Wykaz nielicznych publikacji o tej tematyce podaję w bibliografii.

3 W dalszej części pracy posługuję się skrótami nazw poszczególnych słowników.

${ }^{4} \mathrm{Na}$ tym samym przekonaniu opierałam się - z pozytywnym w moim odczuciu rezultatem - w swoich wcześniejszych pracach z zakresu badań polszczyzny regionalnej. Ich podsumowanie stanowi wydana w Poznaniu w 2011 roku monografia Regionalizmy leksykalne w stownikach doby nowopolskiej.

5 Uwzględnienie tego ostatniego typu wskazówek jest konieczne zwłaszcza przy analizie SL ze względu na brak wypracowanego systemu kwalifikatorów. 
ficznym wskazaniem ${ }^{6}$. Są to przede wszystkim nazwy gatunkowe ryb - piętnaście haseł: korop, kostur, koza, melnica, pomuchla, półryba, rap, rapa, smerla, szmerla, szczubel, szkarp, szweja, wijun, wilczek. Natomiast cztery hasła to określenia ryb innego rodzaju, a mianowicie związane z ich wiekiem bądź wyglądem i rozmiarem: podrybek, podrybka SWil prow. 'mała, młoda rybka, mian. niewyrosły jeszcze łosoś'; stopnik SWil prow. zool. 'ryba'; dopiero w SW - 'narybek trzyletni'; zawianki SWil prow. 'drobne szczupaki'.

Każde interesujące mnie hasło sprawdziłam we wszystkich słownikach, uwzględniając zarówno pozytywne poświadczenia wyrazów hasłowych (czyli potwierdzające ich regionalny charakter), jak i negatywne - kiedy wyraz uznany za regionalny w jednym dziele, $\mathrm{w}$ innych pozbawiony jest kwalifikatora bądź w ogóle pominięty w siatce haseł. W rezultacie dla każdej jednostki sporządziłam pełną metrykę leksykograficzna, co pozwoliło prześledzić los danego hasła w dziełach słownikowych, a co za tym idzie w polszczyźnie.

Dodatkowo dla pełniejszego oglądu wyekscerpowane nazwy ryb skonfrontowałam ze źródłami historycznymi:

- Stanisław Urbańczyk (red.), Stownik staropolski, Wrocław 1953-2002 [Sstp.],

- Maria Renata Mayenowa, Franciszek Pepłowski (t. 1-34), Krzysztof Mrowcewicz, Patrycja Potoniec (od t. 35, do hasła ROWNY), (red.), Stownik polszczyzny XVI wieku, Wrocław 1966-1994, Warszawa 1995 -?) [SPXVI],

- Włodzimierz Gruszczyński (red.), Elektroniczny stownik języka polskiego XVII i XVIII wieku, dostępny on line: http://xvii-wiek.ijp-pan.krakow.pl/pan_klient/ [SJPXVII].

Analiza funkcjonowania regionalnych nazw ryb w słownikach pozwoliła wyodrębnić dwa zasadnicze sposoby konstruowania ich metryki leksykograficznej. Jedną z nich stanowią hasła, których notacje słownikowe uwzględniające ich geograficzne nacechowania kończą się w dziełach z doby nowopolskiej ${ }^{7}$, drugą natomiast - hasła kwalifikowane jako regionalne we współczesnych słownikach języka polskiego.

Spośród jednostek pierwszej wymienionej grupy w dwóch najwcześniejszych słownikach nowopolskich (SL oraz SWil) zostało odnotowane tylko hasło korop. Żywotność pozostałych regionalizmów jest zwykle nieco dłuższa i sięga do SW, w którym to zaznacza się z kolei swoista degradacja słownictwa. Degradacja ta, polegająca na przechodzeniu jednostek z zasobu polszczyzny ogólnej do odmiany gwarowej, uwidacznia się przy porównaniu wskazań SWil oraz SW; SWil kwalifikuje je bowiem jako prowincjonalizmy, natomiast SW uznaje za wyrazy gwarowe. Tendencja ta objęła następujące hasła: melnica, podrybek, podrybka, pomuchla, pólryba, smerla, szmerla, stopnik, szczubel, wilczek, zawianki. $\mathrm{W}$ przypadku hasła wijun mamy natomiast do czynienia ze zjawiskiem odwrotnym - jednostka określona jako wyraz gwarowy w SW, według SJPD zasila warstwę leksyki nacechowanej regionalnie.

Natomiast ze współczesnych słowników języka polskiego najwięcej regionalnych nazw ryb zamieścił PSWP. W ten sposób zakwalifikował on bowiem aż pięć jednostek, które jeżeli były w ogóle uwzględniane w siatce haseł innych słowników, to uznawano je za

${ }^{6}$ Zaznaczam, że terminów wyraz, leksem, hasto, jednostka używam wymiennie, jako synonimów i określam nimi nie tylko formy wyrazowe, ale również odpowiednio kwalifikowane znaczenia wyrazów polisemicznych.

${ }^{7}$ Mimo że SJPD był wydawany poza dobą nowopolską, to uwzględniam go w swojej pracy jako jedno ze źródeł z omawianego okresu. Przemawia za tym fakt, iż zgromadzono w nim jeszcze przedwojenny materiał leksykalny. 
leksemy ogólnopolskie (kostur, koza, rap, rapa), z kolei w jednym wypadku - za gwaryzm: hasło szweja w SW.

Więcej uwagi należało by poświęcić jednostkom kostur, koza, melnica, rap, rapa, pomuchla, smerla, szmerla, szkarp, szweja. Ich leksykograficzne dzieje nie dają się bowiem zamknąć w ogólnych uwagach, zaprezentowanych powyżej.

Najstarsze poświadczenie słownikowe posiada hasło rapa, które wraz z wariantem rap jako regionalne określił PSWP (zoologiczny, regionalny 'nazwa bolenia europejskiego, drapieżnej ryby $\mathrm{z}$ rodziny karpiowatych (Cyprinidae), o wydłużonym, silnie po bokach spłaszczonym ciele, koloru srebrzystego, z płetwami szarymi i czerwonawymi, występuje zwykle w rzekach środkowej i wschodniej Europy; Aspius aspius'). Leksem rapa odnotował SPXVI wieku (zool. 'Aspius aspius (L.), boleń, rap, drapieżna ryba z rodziny karpiowatych (Cyprinidae)') wraz z cytatem z Myśliwca Tomasza Bielawskiego (pierwsze wydanie - 1595) - „Ia rapę náwet wolę niżli kożę”. Kolejny SJPXVII wieku co prawda wymienia postaci rap i rapa, ale towarzyszy im informacja, iż stanowią one ,zalążek hasła”, co niewątpliwie przekłada się na jakość, kompletność opisu słownikowego (artykuł hasłowy ogranicza się bowiem do wskazania paradygmatu odmiany i reprezentowanej części mowy). SL, SWil oraz SW również odnotowują badaną jednostkę, z kolei słowniki późniejsze zamieszczają już tylko w interesującym mnie znaczeniu postać rap, bez informacji o jego regionalnym nacechowaniu.

Wzmiankowana w przytoczonym fragmencie z T. Bielawskiego koza („Ia rapę náwet wolę niżli kożę") odnosi się zapewne do kolejnej wydzielonej przeze mnie regionalnej nazwy ryby. Mimo że pochodzenie autora tych słów (szlachcica T. Bielawskiego) nie zostało całkowicie wyjaśnione, to $\mathrm{z}$ informacji zawartych $\mathrm{w}$ dawnych herbarzach wynika, że ród Bielawskich herbu Zaręba (alternatywnie Zaremba) pochodził z województwa łęczyckiego należącego wówczas do Wielkopolski. Jak podaje z kolei PSWP, leksem koza (zoologiczny, regionalny 'ryba z rodziny karpiowatych (Cyprinidae), o ciele bardzo silnie ścieśnionym w płaszczyznach bocznych i szerokim, tworzącym linie prosta grzbiecie, łukowato wygiętej linii brzucha i otworze gębowym skierowanym ku górze; żyje w morzach Bałtyckim, Czarnym, Kaspijskim i Arabskim, na tarło wędruje do rzek; Pelecus cultratus') to - według informacji zamieszczonej w przykładzie użycia - ,(...) przestarzała nazwa ciosy, używana w Wielkopolsce”.

Natomiast w innych niż PSWP dziełach (np. SW, SJPD, SWJP czy USJP) hasło koza - pozbawione już jakiegokolwiek geograficznego wskazania - odnosi się do innego gatunku i funkcjonuje zwykle z kwalifikatorem zoologiczny dla nazwania 'Cobitis taenia, ryby z rodziny piskorzowatych (Cobitidae), mającej przy otworze gębowym 6 wąsików, a na ciele szeregi brązowych plam, zlewających się w pasy; pospolitej w rzekach o dnie piaszczystym na całym obszarze Eurazji' (SJPD).

Oprócz kozy kolejnym wielkopolskim określeniem ciosy jest kostur. Kwalifikacja taka została zamieszczona ponownie wyłącznie w PSWP w przykładzie użycia: W Wielkopolsce kostury odnotowano w Wirynce, lewobrzeżnym dopływie Warty. W 1958 roku. Nie odnotowują jej natomiast pozostałe słowniki. Co ciekawe, zarówno hasło koza, jak i kostur słownik ten objaśnia identycznie, a jedyną różnicę stanowi usterka literowa w definicji znaczeniowej. Usterka niewielka, ale wprowadzająca pewne zamieszanie. Mianowicie: w definicji jednostki kostur wskazano, że żyje on 'w morzach Bałtyckim, Czarnym, Kaspijskim i Arabskim', natomiast przy haśle koza podano 'morze Bałtyckie, Czarne, Kaspij- 
skie i Aralskie' jako obszar jej występowania. Oczywiście, ryby te można spotkać w Morzu Aralskim (czy raczej Jeziorze Aralskim) a nie Arabskim.

Kolejnymi uwzględnionymi regionalizmami są leksemy smerla i szmerla. W SWil funkcjonują one w znaczeniu 'śliż, śliżyk' jako prowincjonalizmy, z kolei według SW to gwaryzmy. Podana jednak w artykule hasłowym nazwa łacińska (zool. '(Cobitis) ryba koścista, należąca do rzędu Skrzelowatych, brzuchopłetwych, śliżowatych') nie odnosi się do współcześnie tak określanego gatunku (nazwa łacińska: Barbatula barbatula), a pozostaje w związku ze wspomnianą już kozą ('Cobitis taenia, ryby z rodziny piskorzowatych (Cobitidae)').

Jednostka szweja (zoologiczny, regionalny 'ryba z rodziny karpiowatych (Cyprinidae), o ciemnoszarym grzebiecie i srebrzystobiałych bokach oraz brzuchu, żyjąca w europejskich rzekach; Alburnoides bipunceteatus' PSWP) została po razy pierwszy odnotowana jako gwaryzm w SW. W kolejnym SJPD funkcjonuje już jednak jako leksem ogólnopolski. Nieuwzględniona przez MSJP, SWJP, ISJP pojawia się ponownie w niezmienionym znaczeniu dopiero w PSWP oraz USJP. Językowy renesans owego hasła wydaje się być jednak bardziej wypadkową wprowadzonych przez leksykografów ograniczeń w objętości siatki haseł niż odzwierciedleniem rzeczywistego braku owej jednostki w leksyce opisywanego okresu.

Grupę regionalizmów z Pomorza tworzą 3 hasła: pomuchla, melnica oraz szkarp, z których najwcześniejsze słownikowe poświadczenia ma leksem pomuchla. Został on uwzględniony w SJPXVII wieku w znaczeniu 'dorsz, wątłusz, Gadus cellaris', jeszcze bez informacji o obszarze użycia. Natomiast SL, SWil i SW już regularnie zamieszczają w omawianym artykule hasłowym wskazanie geograficzne, np. SL: 'tak w Prusiech zowią rybę Dorsz, Wiel. Kuch. $423^{8}$ ' SWil: prow. 'w Prusiech niegdyś polskich, ryba dorsz'; SW: obok postaci pomuchla zamieszcza również wariant pomuchel i obie uznaje za gwaryzmy, a w artykule pomuchli lokalizuje je następująco.: ,(...) Gdańszczanie wielce cenią dorsza, w Prusiech i w Gdańsku zwanego pomuchel, (...)"”. Powyższe wskazanie utożsamiam z Prusami Królewskimi, czyli prowincjami przyłączonymi do Polski po wojnie trzynastoletniej postanowieniami pokoju toruńskiego, czyli Pomorze Gdańskie, Ziemię Chełmińską, rejony Malborka, Elbląga oraz Warmię, która tworzyła jednakże odrębne Księstwo Warmińskie, podległe miejscowym biskupom. Jest bowiem wątpliwe, by słowniki odnotowały hasła pochodzące z Prus Książęcych. Natomiast nowsze słowniki (USJP, PSWP) nie informują o ograniczeniach w użyciu hasła do konkretnego obszaru, co może świadczyć o tym, iż leksem ten wzbogacił zasób nazw ogólnopolskich.

Inny typ zmiany można dostrzec, analizując metrykę leksykograficzną hasła melnica. W słownikach nowopolskich pojawia się ono regularnie ze wskazaniem geograficznym (SL: ryba morska po Kaszubsku nazwana, iest z rodzaju Łososiów, ale z morza nigdy nie wychodzi i nie iest tak dobra iak łosoś. Ład. H. N. 105; SW: to wyraz gwarowy $<\mathrm{Z} \mathrm{Ka-}$ szubska, zam. *Mulnica>). Słowniki XX-wieczne nie odnotowują owego leksemu, można zatem przypuszczać, iż jednostka ta wycofała się z szerszego obiegu językowego. Funkcjo-

\footnotetext{
${ }^{8}$ Objaśnienie skrótów ze SL zamieszczam w Bibliografii.
} 
nuje ona natomiast najprawdopodobniej w socjolekcie wędkarskim z okolic Kościerzyny jako nazwa gatunku, a także określenie łowiska, w którym ów gatunek występuje?

Ostatniemu hasłu z tego regionu szkarp słowniki poświęciły najmniej uwagi. Zostało ono odnotowane - wraz z lokalizacją geograficzną - wyłącznie w SJPD jako regionalny wariant fonetyczny nazwy ryby skarp (skarp zool. 'in. turbot, Rhanbus maximus, drapieżna ryba z rodziny skarpiowatych (Bothidae), o asymetrycznym, silnie spłaszczonym ciele, pokrytym guzami kostnymi, oczach po jednej stronie głowy; żyje w morzach Europy, jadalna').

\section{Podsumowanie}

Uwzględnione słowniki odnotowały dziewiętnaście regionalnych nazw ryb. Zbiór to ilościowo niewielki, przynoszący określenia gatunków najczęściej poławianych, spożywanych, o największym znaczeniu gospodarczym, co poświadczają również różnorakie źródła historyczne (literatura rybacka, akta prawne (lustracje, inwentarze, przywileje), rachunki, taksy itd. $)^{10}$. Jak udało się wykazać, grupę regionalnych nazw ryb zasilają zarówno jednostki starsze (kwalifikowane jako prowincjonalizmy w słownikach z doby nowopolskiej), jak i hasła uznane za regionalizmy w dziełach młodszych. Mimo przewagi tych pierwszych warto zauważyć, że regionalne nazwy ryb (niekonieczne eksplorowane ze słowników) stanowią zbiór żywy, ciągle się odradzający. Wynika to z faktu, iż wśród amatorów wędkowania znajdują się osoby pochodzące $z$ rożnych regionów Polski, które niejednokrotnie przenoszą do gwary wędkarskiej charakterystyczne dla swojego idiolektu regionalne elementy leksykalne (Piotrowska 2006). Niewątpliwie najaktualniejsze zbiory tego rodzaju haseł możemy znaleźć na stronach internetowych dla pasjonatów wędkowania ${ }^{11}$, chociaż - co należy podkreślić - należy zachować dużą ostrożność w interpretacji informacji tam zamieszczanych.

W podobny sposób należy również podejść do wskazań słownikowych przynajmniej o niektórych rybach. Trzeba bowiem pamiętać, że dawniej wielu nazw używano nieprecyzyjnie: nieraz obejmowały one co najmniej dwa gatunki, a czasem dana nazwa odnosiła się wręcz do innych gatunków niż dzisiaj. Przykładowo: dawne źródła poświadczają, że nazwa śliz obok tak dziś określanego gatunku i wymienianej już kozy (Cobitis taenia), obejmowała prawdopodobnie też piskorza (Misgurnus fosilis) oraz brzanę (Barbus barbus) (Cios 2007: 149); tę ostatnią rozumiano również pod nazwą bolenia (Aspius aspius) (Cios 2007: 103). Dodatkowo dzieła leksykograficzne niekiedy bardzo ogólnikowo definiują nazwy ryb, co przy braku terminologii łacińskiej wprowadza spory chaos, np. Sstp: (Śliz) Śliż zool. 'jakaś mała ryba, może Nemachlius barbatulus, piscis quidam parvus, fortasse Nemachlius barabatulus'; SPXVI: płotka 'Prawdopodobnie: Ryba z rodziny karpiowatych (Cyprinidae), także inna, mająca czerwono zabarwione płetwy; (...)’.

\footnotetext{
9 Wydaje się jednak, iż informacja ta wymaga jeszcze zweryfikowania. Nie znalazła ona jak dotąd w moich badaniach pewnego potwierdzenia, więc być może jest to cecha nie tyle socjolektalna, co idiolektalna.

${ }^{10} \mathrm{~W}$ tym zakresie opieram się na ustaleniach Stanisława Ciosa z monografii Ryby w życiu Polaków od X do $X I X w$.

${ }^{11}$ Ich wykaz przedstawiam w Bibliografii.
} 
Wobec problemów związanych z eksploracją interesującej mnie leksyki z żadnego typu źródeł nie należy jednak rezygnować.

\section{Bibliografia}

Cios S., 2007, Ryby w życiu Polaków od X do XIX w., Olsztyn.

Eschmeyer i in., 2010, Marine fish diversity: history of knowledge and discovery (Pisces), „Zootaxa” 2525, s. $19-50$.

Komar J., Nazwy naszych ryb [online]: http://www.wedkarz.pl/wp-webapp/article/1058 [dostęp 2 listopada 2016].

Kowalska A., 1961, Jeszcze o nazwach szczupaka w pótnocno-wschodnich gwarach Polski, „Poradnik Językowy", s. 24-28.

Kubica-Stęplewska T., 1969, Nazwy geograficzne pochodne od nazw ryb (praca magisterska napisana pod kierunkiem I. Bajerowej), rec.: „Prace Naukowe Uniwersytetu Śląskiego w Katowicach. Prace Językoznawcze", nr 1, s. 126-127.

Kulikowski A., 2005, Wielki herbarz rodów polskich, Warszawa.

Łowiska w okolicach Kościerzyny [online]: http://haczyk.pl/forum/topic/1910-łowiska-w-okolicach-kościerzyny/ [dostęp 2 listopada 2016].

Maciołek M., 2013, Kształtowanie się nazw owadów w języku polskim. Procesy nominacyjne a językowy obraz świata, Katowice.

Piotrowska A.K., 2006, O gwarze wędkarskiej trzydzieści lat później, w: M. Chołody, W. Hamerski, M. Telicki (red.), Człowiek w świecie..., Poznań, s. 153-163.

Piotrowska-Wojaczyk A., 2011, Regionalizmy leksykalne w słownikach doby nowopolskiej, Poznań.

Regionalne nazwy ryb... [online]: http://forum.wedkuje.pl/post/regionalne-nazwy-ryb/160625 [dostęp 2 listopada 2016].

Ryby [online]: https://www.medianauka.pl/ryby [dostęp 2 listopada 2016].

Strutyński J., 1972, Polskie nazwy ptaków krajowych, Wrocław-Warszawa-Kraków-Gdańsk.

Śmieszne zawołania i nazwy ryb [online]: http://zapytaj.onet.pl/Category/028,001/2,26445890,Smieszne_zawolania_i_nazwy_ryb.html [dostęp 2 listopada 2016].

Walczak B., 1997, Kontekst wyrazowy w leksykografii, „Biuletyn Polskiego Towarzystwa Językoznawczego"”, z. 53, s. 157-167.

Walczak B., 2009, „Naszym przodkom wystarczały ryby słone i cuchnace”?, w: S. Mikołajczak, M. Rybka (red.), Pamięci Wolnej i Niepodległej. W 90-lecie odzyskania niepodległości i wybuchu Powstania Wielkopolskiego (Poznańskie Spotkania Językoznawcze), Poznań, s. 145-152.

Wyrwa A.M., 2012, Symbolika ryby i miejsce ryb w diecie klasztornej. Zarys problemu, w: A.M. Wyrwa (red.), Ryby w kulturze i rekultywacja środowiska wodnego. Szkic historyczny i badania hydrobiologiczne, Bydgoszcz, s. 9-48.

Wyrwa A.M. (red.), 2012, Ryby w kulturze i rekultywacja środowiska wodnego. Szkic historyczny $i$ badania hydrobiologiczne, Bydgoszcz.

Żbikowski D., Regionalne nazwy ryb [online]: http://www.fishing.pl/artykuly/ciekawostki/regionalne-nazwy-ryb [dostęp 2 listopada 2016].

\section{Wykaz skrótów}

Ład. H. N. 105 - Ładowski Stanisław, 1783, Historya Naturalna Krolestwa Polskiego, Czyli Zbior krotki [...] Zwierząt, Roślin y Minerałow [...], Kraków. 
ISJP: M. Bańko (red.), Inny stownik języka polskiego, tom 1-2, Warszawa 2000.

PSWP: H. Zgółkowa (red.), Praktyczny słownik wspótczesnej polszczyzny, tom 1-50, Poznań 1994 2005.

SJPXVII: Elektroniczny stownik języka polskiego XVII i XVIII wieku. [online]: http://xvii-wiek.ijppan.krakow.pl/pan_klient/ [dostęp 2 listopada 2016].

SJPD: W. Doroszewski (red.), Stownik języka polskiego, tom 1-11, Warszawa 1958-1969.

SL: S.B. Linde, 1807-1814, Słownik języka polskiego, tom 1-6, Warszawa.

SPXVI: M.R. Mayenowa, F. Pepłowski (tom 1-34), K. Mrowcewicz, P. Potoniec (od tomu 35 do hasła ROWNY) (red.), Stownik polszczyzny XVI wieku, Wrocław 1966-1994, Warszawa 1995-).

Sstp: S. Urbańczyk (red.), Stownik staropolski, Wrocław 1953-2002.

SW: J. Karłowicz, A. Kryński, W. Niedźwiedzki, 1900-1927, Słownik języka polskiego, tom 1-8, Warszawa.

SWil: Słownik języka polskiego, wyd. M. Orgelbrand, część 1-2, Wilno 1861.

SWJP: B. Dunaj (red.), Stownik wspótczesnego języka polskiego, Warszawa 1996.

USJP: S. Dubisz (red.), Uniwersalny słownik języka polskiego, tom 1-4, Warszawa 2003.

Wiel. Kuch. 423 - Wielądek Wojciech Wincenty, ?*, Kucharz doskonaty pożyteczny dla zatrudniajacych się $w$ gospodarstwem... z franc. przetlumaczony $i$ wiela przydatkami pomnożony, Warszawa.

* Praca publikowana w latach 1783, 1786, 1800, 1808 oraz 1812. Nie wiadomo, z którego wydania korzystał Linde, tym bardziej, że nawet nie wymienia on Wielądka w Poczcie pism polskich, w słowniku przytaczanych. Odnotowują go natomiast Stanisław Hrabec i Franciszek Pepłowski w pracy Wiadomości o autorach $i$ dziełach cytowanych w Słowniku Lindego (Warszawa 1963).

\section{AGNIESZKA PIOTROWSKA-WOJACZYK}

\section{Names of fish in regional dialects of the Polish language (based on dictionaries)}

Summary

The article presents a history of selected regional names of fish found in lexicographic works dating from the beginning of the new Polish era till the turn of XX/XXI century. To give a clearer picture of the selected entries, they have been compared with historical sources: Stownik staropolski [Old Polish Dictionary], Stownik polszczyzny XVI wieku [Dictionary of XVI century Polish] as well as with Elektroniczny stownik jezzka polskiego XVII i XVIII wieku [Electronic dictionary of XVII and XVIII century Polish] available online.

Keywords: regional Polish language, lexicography, historical dictionaries, names of fish species 